F. KORTLANDT

\title{
LITHUANIAN STATÝTI AND RELATED FORMATIONS
}

1. Stang distinguishes between two types of $\vec{a}$-present $(1966,323)$ : (1) verbs

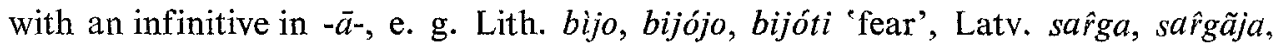
sârgât 'protect'; (2) verbs with an infinitive in -i-, e. g. Lith. sãko, sãke, sakýti 'say', Latv. saka, sacĩja, sacît.

The first type comprises Latv. sargât and Lith. žinóti 'know', ieškóti 'seek', sáugoti 'protect', karóti 'hang', kabóti 'hang', bijóti, and "eine Reihe von Zustandsverba auf -o, -ojo, -oti mit akutierter Wurzelsilbe und wo möglich verlängerter Schwundstufe", which are "Verba durativa, ein Verharren in derselben Lage bezeichnend“, e. g., kýboti 'hang', klúpoti 'kneel', kýšoti 'protrude', rýmoti 'lean', and "Verba ähnlicher Bedeutung mit dem Suffix *-să- und zirkumflektierter Betonung“" (St a ng, 1966, 324), e. g., kumpsóti 'stick (stoopingly)', drybsóti 'lie (slothfully)'. These verbs must be shortly discussed before we can proceed to an examination of the second type.

Lith. žino, Latv. zina represent the nasal present *žinā-, Skt. jänáti 'knows', Toch. A knānat 'you know'. The 1st pl. forms OPr. -sinnimai, Latv. zinim beside zinãm show that the original apophonic alternation between sg. $-n \bar{a}$ - from $*_{-n e{ }_{2}-}$ and pl. $-n$ - from ${ }^{*}-n H_{2}$ - was preserved in Baltic. I have suggested that the same alternation is reflected in the different flexion types of in-verbs, e. g. Latv. dedzina, -inât, Lith. dẽgina, -inti 'burn' (1987b, in fine). I have also argued that Slavic imamb 'I have' is based on 'zbnamb 'I know', SCr. znâm (1985).

Lith. ieško replaces OLith. jiešku (Sı a ng, 1966, 324), OCS. iske 'I seek', Skt. icchati 'seeks'. The origin of the suffix ${ }^{*}-\bar{a}$ - must be sought in the aorist, OCS. iska-, which appears with an additional suffix in the preterit Lith. ieškojo, Latv. iẽskãja.

Lith. sáugo, -oti and Latv. sârga, -ât correspond with Latv. saũdzêt and Lith. sérgèti, respectively, and with OLith. saugti and sergti (Stang, 1. c.). The $\bar{a}$-present must be relatively old in these verbs. I wonder if it was based on the athematic root present of * $p \bar{a}$-, Skt. páti 'protects', which was lost in Baltic and appears with a suffix $-s$ - in Slavic pas- 'tend'. The OLith. root present suggests that there may have been an apophonic alternation between sg. and pl. forms here, too: sg. *saugä-, 
${ }^{"}$ sarg $\bar{a}-$, pl. *saug-, *sarg-. The e-grade of OLith. sergti was evidently taken from sérgèti, cf. gelbti, gélbetti 'save' beside OPr. galbimai 'we help', absergisnan 'protection'.

It is possible that there were more verbs which had $*_{-}-\bar{a}$ - in the singular and zero in the plural of the present tense. Two likely candidates are Lith. giedóti 'sing', raudóti 'weep', Latv. dziêdât, raûdât, which have an OLith. root present and Latv. dial. 1st. pl. dziêdim, raûdim beside the usual thematic forms (Stang, 1966, 323). The alternation in the suffix may have replaced the original apophonic alternation which is attested in Skt. róditi 'weeps', 3rd pl. rudánti, on the analogy of jānăti, iannánti. If this is correct, the analogical development may be dated to a stage when the root-final laryngeal was still a segmental phoneme.

Lith. bijóti, Latv. bijât, OPr. biätwei belongs in a different category. The vocalism of Slavic bojati se points to an original perfect, to be compared with Skt. bibhăya, with a second stem in $*_{-e}-$. If the rise of the second stem can be dated to a stage when the laryngeals were still segmental phonemes, the development o Baltic *bija - from $* b h i H_{2}-e H_{1}$ - is regular. The problem with this hypothesis is thatf therc is little evidence for such late coloring by a contiguous laryngeal in BaltoSlavic. Moreover, there is no supporting evidence for a Baltic present from *-eHrWe may therefore once again look for an explanation in terms of an alternation within the original paradigm. Such an explanation can be proposed if we derive Skt. 3rd pl. bibhyúr (with zero grade ending in a reduplicated formation) from

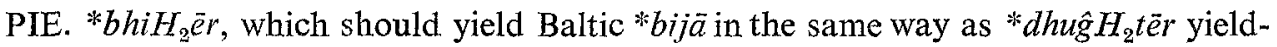
ed Lith. duktễ. This explanation accounts directly for the circumflex ending of Lith. bijo. The acute tone of inf. bijóti and pret. bijójo can easily be analogical.

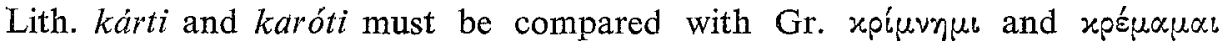
'hang'. The radical nasal may have been lost before the suffixal nasal in the transitive present, as it was in žinóti. The subsequent evolution of the verbal paradigm cannot be reconstructed in detail, but the root vowel of kãria and kãro suggests that the surviving formations were built on a newly created perfect which replaced the original stative. Here again, we are bound to prefer a derivation from 3rd pl. $* k(o) r H_{2} \overline{e r}$ rather than from a stem $* k(o) r H_{2}-e H_{1}$. The verb kabóti beside kabëti was evidently formed on the analogy of karóti, and the same must be assumed for the verbs of "Verharren in der selben Lage" such as rýmoti and drybsóti, which can be translated as 'hanging (around)'. 2. The second type of $\bar{a}$-present comprises causatives, e. g. Lith. statýti 'put', baidýti 'frighten', and original iteratives, e. g. laikýti 'hold', maisýti 'mix', prašyti 'ask', sakýti 'say'. This class corresponds with the causative and iterative verbs with an $o$-grade root vowel which have an $i$-present in Slavic and an aya-present in Sanskrit, e. g. Russ. búdit, Skt. bodháyati 'wakes up'. The fundamental question which must be asked is: how did this class of 
verbs acquire an $\bar{a}$-present in Baltic? The answer to this question is far from obvious because neither the motivation nor the model for an analogical development can easily be detected.

Stang distinguishes between two classes of verbs in $-y t i$ on the basis of the Old Lithuanian and dialectal evidence $(1966,328)$. On the one hand, there is a class of largely causative verbs which have a je-present beside the $\bar{a}$-present of the literary language, e. g. ródžia 'shows', mókia 'teaches'. On the other hand, there is a class of largely iterative verbs which always have an $\vec{a}$-present, e. g. dâro 'does', válgo 'eats'. The semantic distinction between the two classes is doubtful because a number of clearly causative verbs such as baidyt $i$ and statýt $i$ belong to the second class. Moreover, the verb taryti 'say', which is an original iterative with a present tãria, is evidently an ancient formation. I cannot therefore accept Stang's "Annahme, dass das $\bar{a}$-Präsens in den Verben auf -itti zuerst bei den Iterativen Eingang gefunden und sich von hier aus zu den Kausativen verbreitet hat. Wahrscheinlich verbreitete sich diese Flexion zunächst von den $a$-stufigen Iterativen des Typus sãko zu den alten Kausativen mit o-Stufe (ar̃do, baĩdo, stãto).“ $(1966,329)$.

The je-present of verbs in -itti must be related to the Slavic $i$-present. The expansion of the $\vec{a}$-present remains to be explained. In the case of the iteratives, the obvious connection is with the ajje-flexion of Slavic and with the $\bar{a}$-flexion of Germanic and Latin. This formation is not unknown in Baltic: "Als Intensiv- und Iterativsuffix wird -äie/o- zur Erweiterung iterativer $\ddot{l}$-Stämme verwendet, vgl. lit. bráidžioti neben braidýti zu brìsti; ganióti, gáinioti neben ganýti zu giñti usw. "(Sta ng, 1. c.). These verbs actually show that the $\bar{a}$-present cannot be derived from $*_{-}-\bar{j} e$ because they have a present in uncontracted -oja. The metatony in the root shows that the stress was retracted from the stem-final- $i$-before the suffix *-aje- (cf. Kortlandt, 1977, 324). Thus, the comparison of the Baltic $\bar{a}$-present with the Slavic aje-flexion of iteratives does not clarify the origin of the former, but raises the question of why and how the latter was largely replaced by the former in Baltic.

The origin of the $\bar{a}$-flexion has been treated in the scholarly literature in a remarkably unsatisfactory way. Vaillant's theory that *aje- was contracted in polysyllables $(1950,198 ; 1966,366)$ is purely ad hoc and does not explain the lack of contraction in such forms as lándžioja 'creeps', bráidžioja 'wades'. Schmid's comparison of the Baltic ä-present with OHG. greifön 'grab', dansōn 'draw', drangön 'push' $(1963,4)$ is inconclusive. Stang suggests that Baltic and Germanic had a semi-thematic $\bar{a}$-flexion which can be derived from an earlier thematic type in $*_{-} e \mathrm{H}_{2} e-(1966,330)$. There is no supporting evidence for this view, which ignores Cowgill's demonstration that there is nothing in the Germanic material which cannot be explained from *aje-(1959). According to the only recent theory which has come to my attention, "la terminazione *aăie/o- di formazioni denominative, 
costruite su 'nomina actionis' in ${ }^{*}-\bar{a}$ - (con vocalismo radicale $o$ ), è stata secondariamente interpretata come suffisso deverbativo. I deverbativi costruiti con tale suffisso potevano, come i deverbativi sopra esaminati, acquisire il valore semantico secondario di iterativi o causativi" (Michelini, 1977, 253). Up to this point I fully agree. The problem is the elimination of $*_{-j-}$, which is in Michelini's view an analogical development $(1977,255)$ : when $*_{-j} \bar{a}$ - yielded $*_{-} \bar{e}$ - in the preterit, the

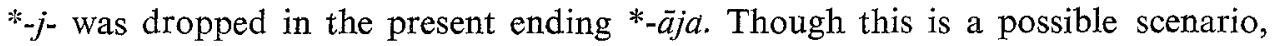
the theory does not explain the loss of the stem-final $*_{-}-\ddot{a}$ - in the preterit, its spread. in the present, and the distribution of the resulting flexion types.

Let me briefly sum up what I regard as the essence of the problem. We have to start from a class of causatives and iteratives with a present in *-eie-and a class of intensives and iteratives of denominative origin with a present in *-aie-, and we end up with Lith. sãko, sãke as the reflex of both classes. A part of the verbs, mostly causatives but also taryti (which has no $\vec{a}$-present), are attested with a je-present, which may be identified with the Slavic $i$-flexion. The other verbs, mostly iteratives but also such causatives as statýti and baidýt $i$, have an $\bar{a}$-present everywhere.

Besides, there are classes of causatives, iteratives, and denominatives in Lith -inti, Latv. -inât, which are closely related to the verbs in $-y t i$, $-\hat{t}$. Stang writes the ollowing $(1966,371)$ : “Wir können also zwei urbalt. Typen aufstellen: a) einen wurzelbetonten Typus mit dem halbthemat. Suffix $-i n \bar{a}-; b$ ) einen suffixbetonten Typus mit dem themat. Suffix -ina-.

Der erste Typus umfasst Denominativa, und im Lit. auch Kausativa ohne $o$ Stufe in der Wurzelsilbe. Der zweite Typus umfasst Kausativa, vielleicht auch Iterativa, mit $\boldsymbol{o}$-Stufe.

Es ist wahrscheinlich, dass das denominative Suffix *-inta- ursprünglich $\mathrm{Ab}$ leitungen aus nominalen $n$-Stämmen bildete. [...]

Grössere Schwierigkeit macht das Suffix -ina-. Es scheint deverbativen Ursprungs zu sein. Da es in den Kausativen mit o-Stufe sein Zentrum hat, liegt die Annahme nahe, dass der alte Kausativtypus mit $o$-Stufe (lit. ardy $t i$, sl. pojiti) beim Zustandekommen des -ina- Typus eine Rolle gespielt hat".

As I pointed out earlier, I think that -inā- and -ina- represent the sg. and pl. stem forms of the same paradigm and can be compared with Skt. jänăti, jänánti. The causatives with an $o$-grade root vowel and stress on the suffix, e. g. Lith. sodina, OPr. saddinna, resemble the type of Skt. sädáyati 'seats' too much to be an independent formation. We may therefore wonder if the $\bar{a}$-presents of verbs in $-y t i$, $-\hat{i} t$ and the partly thematic flexion of deverbatives in -inti, -inât actually represent different forms from the same paradigm. This is indeed the solution I am going to propose. 3. Looking for a model which is strong enough to generate a clas, of causative verbs which have an $\bar{a}$-present with $i$-forms and alternate with $i n$-verbs, 
we arrive at the reduplicated present of the PIE. root*ste $H_{2^{-}}$'stand', Gr. " $\sigma \tau \eta \eta \mu$. This forces us to have a brief look at the fate of the reduplicated presents in Baltic.

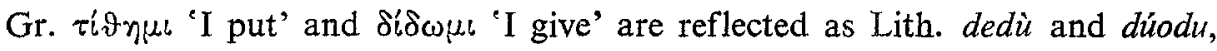
OLith. demi and Latv. duômu. The difference between the two verbs shows that the long vowel in the latter verb is a result of Winter's law and that we have to derive these forms from *dhedhH $H_{1} m i$ and $* d o d H_{3} m i$; this reconstruction also explains the final stress of Slavic damb and the broken tone of Latv. duômu, which are incompatible with a proto-form *doHmi (cf. Kortlandt, 1977, 323). The reduplication syllable evidently adopted the timbre of the root vowel, cf. also OCS. deždo, which can be compared with Lith. dedù. It is usually assumed that there is no trace of a form corresponding to Gr. " $\sigma \tau \eta \mu \iota$ in Balto-Slavic. I would now like to advance the hypothesis that there was a paradigm 3rd sg. *stastāti, 3rd pl. *stastinti, reflecting PIE. *stiste $H_{2} t i$, *stest $H_{2} n t i$, which provided the model for the Baltic causative formations. (For the reduplication syllable cf. Skt. 3rd sg. sisakti, 3rd pl. sáścati 'accompany', and Kortlandt, 1987a, 222.)

The hypothesis that the Baltic $\bar{a}$-presents must largely be derived from a paradigm *stastäti, *stastinti receives strong support from the existence of a class of iterative verbs with a stā-present and an o-grade root vowel, e. g. Lith. barstýti 'strew', dangstýt $i$ 'cover', Latv. stâstît 'tell': "Da die stä-Verba vielfach klare Iterativa sind und da sie grundsätzlich dieselbe Ablautstufe aufweisen, wic die primitiven Iterativa auf -it $i$, sind sie kaum unabhängig von diesen zu erklären“ (Sta ng, $1966 ; 327$ ). It also offers an explanation for the rise of causative verbs in Lith. - dyti, -dinti, Latv. -dit, -dinât: these verbs apparently adopted the -d- of 3rd pl. *dedinti, *dódinti and the $\bar{a}$-flexion of *stastāti. As a result, $-d$ - could be used as a hiatus filler in these classes, cf. Lith. baidýti 'frighten', where the circumflex of baĩdo points to loss of the root-final laryngeal and addition of - $d$-from *dedinti, but Latv. baídît, where the stretched tone cannot have been taken from bittiês 'fear' and may reflect the acute of $*$ dodinti added to the same form of the root. The original formation was preserved in OPr. pobaiint. The presence of the acute tone in *dodinti and its absence from *dedinti account for the coexistence of $d$-causatives with and without metatony, e. g. Lith. gim̃do, gimdo 'gives birth', raĩ do, rámdo 'soothes' (cf. Būga, 1924, 274).

Perhaps the most salient feature of the Baltic verbal system is the absence of a distinction between 3rd sg. and 3rd pl. forms. As I have pointed out elsewhere (1979, $62 \mathrm{f}$. and 65), I think that this unification originated from the phonetic merger of 3rd sg. *-je and 3rd pl. *-jo into -ja in the je-presents. As a result of this development, the form *stastinti could be interpreted either as a $3 \mathrm{rd}$ pl. form of an $i$-present alternating with an $\vec{a}$-present in the singular, or as a $3 \mathrm{rd}$ sg. form of an in-present. The latter interpretation caused the paradigm to adopt the flexion of Skt. jānáti, jānánti. 
The original absence of a laryngeal from the nasal suffix in in-verbs is still evident from such infinitives as Lith. dẽginti 'burn', where de Saussure's law did not operate. It follows that the introduction of the acute tone into such forms as sodinti is recent. I regard the type of gyvénti 'live' as derived from the verbs in -ét $i$ by means of a nasal infix (cf. Siang, 1966, 373).

The verb *stastä-, *stasti- has not been preserved unchanged. The reduction in Lith. statyti and OPr. preistattinnimai 'we put before' is reminiscent of Latin steti 'I stood'; it may have been conditioned by a reinterpretation of the verb as a denominative (cf. Fraenkel, 1965, 897). Latv. stãdit 'plant' may be a recent formation, but stâstît 'tell' has a good chance of being a direct continuation of the verb we are looking for, cf. the semantic development of ORuss. déjetb 'says', French $i l$ fit 'he said', English to state.

4. The main point which remains obscure now is the motivation for the elimination of eie-presents in Balto-Slavic. This problem must be viewed in relation to the development of the perfect.

There are two major sources of $\bar{e}$-verbs with an $i$-present in Balto-Slavic. On he one hand, there is a class of ablauting presents with $*_{-e} i$ - in the singular and $*_{-i}$ $\mathbf{i}_{n}$ the plural, which is preserved in Skt. kșéti 'dwells', kșiyánti. This type appears to have left a trace in OPr. turei, turri 'has, have' (cf. Kortland t, 1987b). It is reflected as a jc-present with a zero grade root vowel in Skt. buidhyate 'wakes', mánya-

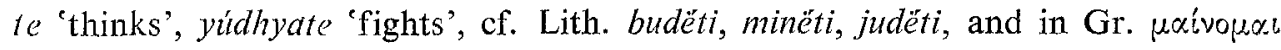

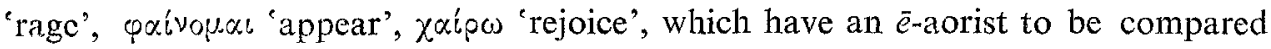
with Lith. $-\ddot{e} t i$. It seems probable to me that this is also the origin of the flexion type of Latin capiō 'take', cf. especially cupiō 'desire', Skt. kúpyant- 'angry'.

On the other hand, $\bar{e}$-verbs with an $i$-present continue perfects of roots in a resonant (cf. Van Wijk, 1933, 138; Kortlandt, 1979, 55 f.):

Old Church Slavic

1st sg. vědě, gorile

2nd sg. věsi, goriši

3rd sg. věstz, goritz

1st pl. věms, Lith. gãrime

2nd pl. věste, Lith. gãrite

3rd pl. vědetz, goretz
Balto-Slavic

$$
\begin{aligned}
& \text { *woiddi, *gorai } \\
& \text { *woisai, *gorișai } \\
& \text { *woidei, *gorei } \\
& \text { *woidme, *gorime } \\
& \text { *woiste, *gorite } \\
& \text { *woidin }(t i), \text { *gorin }(t i)^{1}
\end{aligned}
$$

1 It actually seems probable to me that the 3 rd pl. ending was still $*_{-i r}$ at this stage. The main point is that the comparative Slavic evidence points to a secondary ending in the $i$-flexion (cr. Kortlandt, 1979, $60 \mathrm{f}$.), which can only have originated in the perfect, whereas the added ${ }^{*}-i$ in the sg. forms must have been taken from the athematic primary endings (o.c., 55). The perfect ending *-ir was neither primary nor secondary. 
For the 2nd sg. ending cf. OPr. etskisai 'you rise', an athematic form which is best compared with Latin cieo 'put in motion' and may represent an $i$-present of the PIE. root $* k e H_{1} i$ - with generalization of the plural stem form attested in etskimai 'we rise', cf. the same root in kylo 'wagtail', Lith. kiele. Another form which may be mentioned in this connection is OPr. quoi 'want(s)', which looks like a backformation on the basis of 2 nd sg. "quoisai, cf. Lith. kviẽsti 'invite'.

It now appears that there may have been some interference between 3rd sg. $*_{-}-e i$ in the perfect and *-eie in the causative, especially because both categories were characterized by 0 -grade root vocalism. As a result, the causative lost its thematic flexion in Balto-Slavic. This is a major development which distinguishes the branch from other Indo-European languages. We may therefore wonder if the category of $i$-verbs with an $\bar{a}$-present is a common Balto-Slavic development. It is certainly common. Baltic, as is clear from OPr. läiku, laikūt 'hold', perbānda 'tempts', perbandāsnan 'temptation', maysotan 'mixed', Lith. laikýti, bandýti, maisýti. Note that OPr. teickut 'create', pret. teikü has an e-grade root vowel and reflects a different formation, cf. endeirā 'saw', dereis 'see!'; it must be compared with Lith. teîkti 'give', not with táikyti 'aim'.

There are indeed traces of an $\bar{a}$ flexion in $i$-verbs in SCr. hódati 'walk', nósati 'carry', vódati 'lead', vózati 'drive', all 'back and forth'. Though the long rising tone is clearly recent, "la formation est ancienne" (Vaillant, 1966, 359). There are a number of Slavic nouns in -atai which are derivatives of verbal $\bar{a}$-stems: xodatai 'mediator', povodatai 'guide', prělogatai 'scout', vozatai 'carrier' (Vailla nt, l. c.). The isolated character of these $\vec{a}$-stems, which can be compared with Latv. vadât 'lead about' beside vadit 'lead', shows that they cannot be denominatives. They may have provided the model for the secondary imperfectives in - $(j)$ ati of verbs in $-i t i$, which subsequently adopted the flexion of the far more numerous denominatives in the same way as Latv. vadât and Lith. vadžióti 'lead about'. The derivation of nomina agentis in *-tajj-from verbal stems is a Balto-Slavic process, cf. OPr. artoys, Lith. artójas, Russ. rátaj 'ploughman'. I thus conclude that the $\bar{a}$-flexion of $i$-verbs once existed in Slavic, but was lost as a result of later developments.

5. The $o$-grade stem forms of $3 \mathrm{rd} \mathrm{sg}$. perfect *ei and causative *-eic could not only be differentiated through the replacement of the latter by an $\bar{a}$-present, but also through a further differentiation of the stem formation. The latter development appears to have occurred in the separate branches of Balto-Slavic. As I pointed out above, Russ. 3rd sg. boitsja 'fears' and OPr. 3rd pl. bia may represent Balto-Slavic $3 \mathrm{rd}$ sg. *bojei, 3rd pl. *bijār. The o-grade root vowel was generalized in Slavic, where the causative was lost, while Baltic has preserved the $o$-grade in the causative OPr. pobaiint, Lith. baidyti, Latv. baiditt, and generalized the zero grade in OPr. biātwei, Lith. bijóti, Latv. bijât, cf. also the deverbative noun OPr. biăsnan, Russ. bojázn'. 
It will be clear from the foregoing that to my mind stem alternation between sg. and $\mathrm{pl}$. forms of the same paradigm was a regular feature of Balto-Slavic. Against this background it is reasonable to assume that Lith. stovi and Russ. stoját 'stand' also reflect the sg. and pl. stem forms of a Balto-Slavic perfect, and that the Slavic causative staviti relates to Lith. stovêti in the same way as OPr. isstallit 'perform' relates to stallit, stalle- 'stand'. It is therefore necessary to have a look at the PIE. perfect.

The Indo-European proto-language had two types of perfect, viz. reduplicated (resultative) and unreduplicated (stative). The distinction between the two is best preserved in Germanic, where they are reflected as strong preterits and perfect presents (Präteritopräsentia), respectively, e. g. Gothic haihait 'called', wait 'know'. The $3 r d$ pl. ending was $*_{-} r$ in reduplicated and probably $*_{-}-\bar{r}$ in unreduplicated perfects, while the $3 r d$ sg. ending was *-e in both categories, except for stems in a laryngeal, where the root was obscured because the distinctive coloring of the laryngeal was lost after the $o$-grade root vowel (cf. Kortlandt, 1980). The form in *oHe was evidently replaced by a form in *-êu in PIE. times already, cf. Skt. dadháu 'put', papráu 'filled', tasthảu 'stood', dadảu 'gave', jajñáu 'knew', Latin plēvit, sēvit 'sowed', novvit, OEng. sēow, cnēow. This may originally have been the loc. sg. form of a deverbal $u$-stem (cf. Charpentier, 1913, 98, 101, and Hirt, 1913, 315, fn. 1), of which the participle in *-ues- is a derivative, e. g. Skt. dadus- 'having given'. I therefore reconstruct Balto-Slavic 3rd sg. * stāu. 3rd $\mathrm{pl} .{ }^{*}$ stär, both with a non-acute long vowel, from earlier ${ }^{*} s t H_{2} \bar{e} u,{ }^{*} s t H_{2} \bar{e}$.

OLith. stóvmi ${ }^{C}$ I stand' is directly based on Balto-Slavic *stāu (cf. Van Wijk, 1933, 135), but adopted the acute tone of the verb stóti. The expected circumflex is preserved in dẽvi 'wears', which represents *dêu, Skt. dadháu. When the plural form *stär lost its final -r, Slavic replaced *stä by *sta', where -' denotes the glottal stop which developed from the laryngeals, and this form served as a basis for the creation of the present *sta'ei and the preterit 'sta' $e$ ' which eventually yielded Russ. stoit, stojat'. The form "stāu served as a basis for the creation of the Slavic causative staviti, which adopted its acute tone perhaps from stati, but more probably from baviti, Skt. bhāváyati 'causes to become', PIE. *bhoHueie of the root "bhe $\mathrm{H}_{2} u-$ -

The theory advanced. here offers an explanation for the non-acute long root vowel of Slavic -stavati, -davati, -znavati, which can now be derived from ä-presents based on Balto-Slavic *stāu, *dōu, *žz(i) nōu. These verbs are the imperfective counterparts of perfective iteratives, e. g. pf. razdajati, ipf. razdavati 'distribute', as distinct from pf. prědati, ipf. prědajati 'deliver' (cf. Vailla nt, 1966, 473). They apparently provided the model for the spread of lengthened grade root vocalism in causatives and iteratives, e. g. SCr. páliti 'burn', váriti 'boil', sáditi 'plant', polágati 'put', prelámati 'break', istákati 'pour', pf. polòżiti, prelòmiti, istòčiti. The lengthen- 
ed grade root vowel distinguishes these imperfective causatives and iteratives from the Slavic verbs in -ět $i$ which continue earlier perfects, e. g. polět $i$, vbrět $i$, and original statives, such as sěděti (with radical -е̌- from Winter's law) and ležati.

Thus, I think that Lith. statýti reflects Balto-Slavic 3rd sg. *stastäti, 3rd pl. *stastinti, and that this paradigm played a crucial role in the development of the verbal system.

\section{REFERENCES}

Būga, 1924 - Būga K. Die Metatonie in Litauischen und Lettischen// ZfVS.52.1924. S. $250-302$.

Charpentier, 1913 - Charpentier J. Die altindischen Perfektformen des Typus dadäú // IF. 1913. 32. S. 92-102.

Cowgill, 1959 - Cowgill W. The Inflection of the Germanic $\bar{\sigma}$-Presents//Language. 1959. Vol. 35/1. P. 1-15.

Fraenkel, 1965 - Fraenkel E. Lirauisches etymologisches Wörterbuch. Heidelberg; Göttingen, 1965. Bd. 2.

Hirt, 1913 - Hirt H. Fragen des Vokalismus und der Stammbildung im Indogermanischen // IF. 1913. 32. S. 209-318.

Kortlandt, 1977 - Kortlandt F. Historical Laws of Baltic Accentuation//Baltistica. 1977. Vol. 13(2). P. 319-330.

Kortlandt, 1979 - Kortlandt F. Toward a Reconstruction of the Balto-Slavic Verbal System // Lingua. 1979. Vol. 49. P. 51-70.

Kortlandt, $1980-$ Kortlandt F. $H_{2} \mathrm{o}$ and $\mathrm{oH}_{2} / /$ LP. 1980. 23. P. 127-128.

Kortlandt, 1985 - Kortlandt F. Slavic imamí // IJSLP. 1985. 30/31. P. 235-239.

Kortlandt, 1987a - Kortland t F. Archaic Ablaut Patterns in the Vedic Verb // Festschrift for Henry Hoenigswald. Tübingen, 1987a. P. 219-223.

Kortlandt, 1987b - Kortland t F. The Formation of the Old Prussian Present Tense// Baltistica. 1987b. Vol. 23(2). P. 108-115.

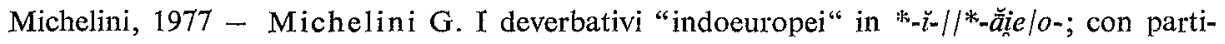
colare riferimento alle lingue baltiche // Baltistica. 1977. Vol. 13(1). P. 250-260.

Schmid, 1963 - Schmid W. P. Studien zum baltischen und indogermanischen Verbum. Wiesbaden, 1963.

Stang, 1966 - Stang C. S. Vergleichende Grammatik der baltischen Sprachen. Oslo, 1966.

Vaillant, 1950 - Vaillan t A. Grammaire comparée des langues slaves I: Phonétique. Lyon, 1950.

Vaillant, 1966 - Vaillant A. Grammaire comparée des langues slaves III : Le verbe. Paris, 1966.

Van Wijk, 1933 - Van Wijk N. Le problème des prétérito-présents slaves et baltiques // SB. 1933. 3. P. $134-139$. 